\title{
Optimum Preparation of Candida albicans Cell Wall Extra (CAWE) for the Mouse Model of Kawasaki Disease
}

\author{
Yukako Yoshikane, Tamaki Cho, Mitsuhisa Koga, \\ Seiji Haraoka, and Atsushi Ogawa
}

\author{
Keywords \\ Kawasaki disease $\cdot$ Animal model $\cdot$ Candida albicans
}

Kawasaki disease is the most common acute systemic vasculitis of unknown etiology in children [1] and can cause inflammation of the coronary arteries leading to aneurysms. Candida albicans extract is one of the materials commonly used to induce coronary arteritis in a mouse model of Kawasaki disease [2,3]. Here we report an optimized method for preparing $C$. albicans cell wall extra (CAWE).

1. $80 \%$ of the mice administered CAWE that had been alkalinized at $87^{\circ} \mathrm{C}$ showed massive inflammation around the origin of the coronary arteries. By contrast, the mice administered CAWE that had been alkalinized at $97{ }^{\circ} \mathrm{C}$ showed no inflammation.

2. $60 \%$ of the mice administered CAWE adjusted to $640 \mu \mathrm{g}$ protein/mouse died within 2 days whereas $100 \%$ of the mice administered CAWE adjusted to $320 \mu \mathrm{g}$ protein/mouse exhibited inflammation but survived.

\footnotetext{
Y. Yoshikane $(\varangle) \cdot$ A. Ogawa

Department of Pediatrics, Fukuoka University, Chikushi Hospital,

Fukuoka, Fukuoka, Japan

e-mail: yyoshika@ fukuoka-u.ac.jp

T. Cho

Department of Oral Microbiology, Fukuoka Dental College, Fukuoka, Fukuoka, Japan

M. Koga

Faculty of Pharmaceutical Sciences, Fukuoka University, Fukuoka, Fukuoka, Japan

S. Haraoka

Department of Pathology, Fukuoka University, Chikushi Hospital,

Fukuoka, Fukuoka, Japan
} 
In conclusion, high heat processing causes poor pathogenicity and high protein content causes excessive pathogenicity. Therefore, CAWE that has been heat processed at $87{ }^{\circ} \mathrm{C}$ and adjusted to $320 \mu \mathrm{g}$ protein/mouse is optimal for the mouse model of Kawasaki disease.

Acknowledgment We thank Kate Fox, DPhil, from Edanz Group (www.edanzediting.com/ac) for editing a draft of this manuscript.

\section{References}

1. Kawasaki T, Kosaki F, Okawa S, Shigematsu I, Yanagawa H. A new infantile acute febrile mucocutaneous lymph node syndrome (MLNS) prevailing in Japan. Pediatrics. 1974;54:271-6.

2. Murata H. Experimental candida-induced arteritis in mice. Relation to arteritis in the mucocutaneous lymph node syndrome. Microbiol Immunol. 1979;23:825-31.

3. Takahashi K, Oharaseki T, Wakayama M, Yokouchi Y, Naoe S, Murata H. Histopathological features of murine systemic vasculitis caused by Candida albicans extract—an animal model of Kawasaki disease. Inflamm Res. 2004;53:72-7.

Open Access This chapter is licensed under the terms of the Creative Commons Attribution 4.0 International License (http://creativecommons.org/licenses/by/4.0/), which permits use, sharing, adaptation, distribution and reproduction in any medium or format, as long as you give appropriate credit to the original author(s) and the source, provide a link to the Creative Commons license and indicate if changes were made.

The images or other third party material in this chapter are included in the chapter's Creative Commons license, unless indicated otherwise in a credit line to the material. If material is not included in the chapter's Creative Commons license and your intended use is not permitted by statutory regulation or exceeds the permitted use, you will need to obtain permission directly from the copyright holder.

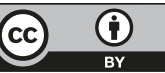

